\title{
KEMAMPUAN PEMAHAMAN KONSEP MATEMATIKA DENGAN MENERAPKAN PENDEKATAN PEMBELAJARAN KONTEKSTUAL MELALUI MODEL PEMBELAJARAN KOOPERATIF THINK-PAIR-SHARE BEREMPAT DAN KEMUNCULAN KOMPONEN PEMBELAJARAN KONTEKSTUAL
}

\author{
Nola Nari \\ Program Studi Tadris Matematika Jurusan Tabiyah STAIN Batusangkar \\ Korespondensi: Jl. Pabidikan No. 160 Kabun Pulasan RT 03/RW 06 Bukittinggi Sumatera Barat \\ E-mail: nola_purple@yahoo.co.id
}

\begin{abstract}
One of the causes of students' low in comprehending concepts in learning mathematics is the teacher centered teaching method. One alternative that can be proposed to solve the problem is by employing contextual learning approach through TPS-Berempat cooperative learning. This study therefore aimed at figuring out whether the students' concept which was tanght by TPS-Berempat cooperative learning model is better than that by the conventional one and whether the components of the model existed. The participants of the research were the seventh grade students of SMP N 20 Padang in 2009/2010 academic year. Quasi Experimental method using Posttest Control Group Design was employed. Experimental group was treated by using contextual learning approach while the control one by using conventional. The data was taken from achievement test. The result of the analysis showed that the components of the contextual learning appeared well and students' comprehension toward the concept which was tanght by contextual learning in mathematics was better than that of by the conventional one.
\end{abstract}

Kata kunci: pemahaman konsep, pendekatan kontekstual, kooperatif TPSberempat

\section{PENDAHULUAN}

$\mathrm{P}$ embelajaran matematika di sekolah bertujuan mengembangkan kompetensi matematika yang diharapkan dicapai, yang meliputi:

1. pemahaman konsep matematika yang dipelajari, kemampuan menjelaskan keterkaitan antar konsep dan mengaplikasikan konsep atau algoritma secara luwes, akurat, efisien, dan tepat dalam pemecahan masalah,

2. kemampuan mengkomunikasikan gagasan dengan simbol, tabel, diagram, atau media lain untuk memperjelas keadaan atau masalah,
3. kemampuan menggunakan penalaran pada pola atau sifat serta kemampuan melakukan manipulasi matematika dalam membuat generalisasi, menyusun bukti atau menjelaskan gagasan dan pernyataan matematika,

4. kemampuan merancang atau membuat model, menyelesaikan model dan menafsirkan solusi yang diperoleh dalam pemecahan masalah dan

5. sikap menghargai kegunaan matematika dalam kehidupan yaitu: rasa ingin tahu, perhatian dan minat dalam mempelajari matematika, sikap 
ulet dan percaya diri dalam pemecahan masalah, (Depdiknas, 2006: 5).

Dalam pelaksanaannya, pelajaran matematika oleh siswa pada umumnya dipandang sebagai pelajaran yang "sulit", karena dipenuhi rumus-rumus. Pendekatan pembelajaran matematika yang digunakan guru cendrung menjadikan siswa merasa bosan selama kegiatan pembelajaran berlangsung. Akibatnya, pentingnya matematika sebagai bagian dari kehidupan tak dapat mereka rasakan manfaatnya. Padahal menurut Cockroft dalam Mulyono (1998: 253) menyatakan bahwa: "matematika perlu diajarkan kepada siswa karena (1) selalu digunakan dalam segi kehidupan, (2) semua bidang studi memerlukan keterampilan matematika yang sesuai, (3) merupakan sarana komunikasi yang kuat, singkat, dan jelas, (4) dapat digunakan untuk menyajikan informasi dalam berbagai cara, (5) meningkatkan kemampuan berpikir logis, ketelitian dan kesadaran keruangan, dan (6) memberikan kepuasan terhadap usaha memecahkan masalah yang menantang".

Dalam menghadapi masa depan yang penuh dengan persaingan dan tantangan, diperlukan kecakapan dan keterampilan tertentu untuk dapat mengatasi problematika dan dinamika zaman yang terus berkembang. Permasalahan yang terus berdatangan dalam kehidupan perlu disikapi secara cermat, efektif, dan efisien agar diperoleh solusi yang optimal. Untuk mengatasinya diperlukan kemampuan berpikir yang logis, rasional, sistematis, kritis, dan kreatif yang mampu memecahkan permasalahan.

Tidak dapat dipungkiri bahwa matematika sangat berkaitan erat dengan fenomena kehidupan, mulai dari fenomena yang sederhana sampai fenomena yang kompleks. Penguasaan matematika sangat diperlukan dalam kehidupan. Penguasaan matematika ini meliputi kemampuan memahami isi (content) matematika itu sendiri, memahami kaitan antar konsep matematika (mathematical connection), mengemukakan ide matematika kedalam bahasanya (mathematical communication), serta menyusun model matematika dalam menyelesaikan permasalahan (mathematical problem solving). Pembelajaran matematika yang dapat memberikan bekal kompetensi hendaklah pembelajaran yang lebih bermakna bagi peserta didik. Oleh karena itu butuh pendekatan yang sesuai dalam pembelajaran matematika yang salah satunya pendekatan kontekstual sehingga pembelajaran matematika akan semakin bermakna.

Pemahaman konsep siswa dalam belajar matematika adalah salah satu tujuan penting dalam pembelajaran, memberikan pengertian bahwa materimateri yang diajarkan kepada siswa bukan sebagai hafalan tetapi lebih jauh lagi yaitu penanaman dan pemahaman konsep. Pemahaman matematik juga merupakan salah satu tujuan dari setiap materi yang disampaikan oleh guru, sebab guru merupakan pembimbing siswa untuk mencapai konsep yang diharapkan. Pendidikan yang baik adalah usaha yang berhasil membawa siswa kepada tujuan yang ingin dicapai yaitu agar bahan yang disampaikan dipahami sepenuhnya oleh siswa. Pemahaman sebagai terjemahan dari istilah understanding yang diartikan sebagai penyerapan arti suatu materi yang dipelajari.

Kemampuan memahami konsep menjadi landasan untuk berpikir dalam menyelesaikan persoalan. Dahar (1989: 64) menyatakan bahwa "belajar konsep merupakan hasil utama pendidikan". Konsep-konsep merupakan pilar-pilar pembangun berpikir. Konsep-konsep merupakan dasar bagi proses-proses mental yang lebih tinggi untuk merumuskan prinsip-prinsip dan generalisasigeneralisasi.

Permasalahan yang sering timbul dalam pembelajaran matematika secara garis besar dapat bersumber dari dua hal 
yaitu: guru dan siswa. Berdasarkan wawancara yang dilakukan dengan beberapa orang guru yang mengajar di tingkat SMP, dapat diketahui bahwa hampir sebagian besar guru masih menggunakan cara lama yaitu pendekatan konvensional (metode ceramah). Guru merasa bahwa metode ini tepat digunakan karena mereka dapat lebih leluasa dalam mengatur waktu dan menyampaikan materi beserta contoh soal kepada siswa sebanyak mungkin. Kondisi yang terjadi selama ini mempersempit ruang gerak siswa sehingga selama proses pembelajaran berlangsung siswa lebih bersifat pasif dan menghambat ide-ide cemerlang yang seharusnya muncul selama pembelajaran menjadi terendapkan.

Tujuan penelitia ini adalah melihat kemunculan komponen pendekatan pembelajaran kontekstual dan pemahaman konsep matematika siswa melalui model Think-Pair-Share-Berempat. Tulisan ini disarikan dari hasil penelitian yang berjudul pengaruh penerapan pendekatan pembelajaran konstekstual melalui model pembelajaran Think-Pair-Share-Berempat terhadap kemampuan matematika siswa kelas VII SMP N 20 Padang.

\section{METODOLOGI PENELITIAN}

Penelitian ini menggunakan pendekatan kuantitatif dalam bentuk Quasi Experimental Design. Rancangan penelitian yang digunakan adalah PosttestOnly Control Design yang terdiri dari dua kelompok. Variabel pada penelitian ini terdiri dari (a) variabel bebas yaitu pendekatan pembelajaran, (b) variabel terikat yaitu kemampuan matematika yang meliputi pemahaman konsep pada materi aritmatika sosial. Populasi dalam penelitian ini adalah siswa kelas VII tahun pelajaran 2009/2010 di SMPN 20 Padang yang terdiri dari 8 kelas. Teknik pengambilan sampel yang digunakan dalam penelitian ini adalah Random Sampling berdasarkan nilai ujian tengah semester. Berdasarkan hasil analisis melalui serangkaian uji statistik terhadap nilai ujian tengah semester tersebut maka dapat disimpulkan bahwa kesemua kelas berdistribusi normal dan homogen serta tidak terdapat perbedaan yang signifikan antar kelas. Pengambilan sampel dilakukan secara acak sehingga terpilih kelas VII 5 dengan jumlah siswa 39 orang dan VII 6 dengan jumlah siswa 38 orang. Kelas VII 6 ditetapkan sebagai kelas eksperimen yang mendapatkan perlakuan dimana pembelajarannya menggunakan pendekatan kontekstual dengan pembelajaran kooperatif tipe TPS-berempat sedangkan kelas VII 5 sebagai kelas kontrol dimana pembelajarannya menggunakan pendekatan konvensional.

\section{ANALISIS HASIL PENELITIAN}

Anlisis hasil penelitian dilakukan untuk melihat beberapa hal yang terkait dengan pembelajaran matematika pada materi aritmatika sosial, yang meliputi: kemampuan pemahaman konsep matematika dan kemunculan 7 komponen pembelajaran kontekstual selama pembelajaran.

\section{Pengamatan Kemunculan Komponen Kontekstual Melalui Model Pem- belajaran Kooperatif TPS-Berempat di Kelas}

Untuk melakukan pengamatan terhadap kemunculan komponen kontekstual melalui pembelajaran kooperatif TPS-berempat digunakan lembar observasi yang diisi setiap kali tatap muka dengan bantuan LKS yang telah divalidasi untuk merangsang munculnya 7 komponen pembelajaran kontekstual.

\section{Konstruktivisme}

Menurut Yager dalam Nurhadi (2004: 41), prosedur pembelajaran konstruktivisme meliputi: (a) Carilah dan gunakanlah pertanyaan dan gagasan siswa untuk menuntun pembelajaran dan 
keseluruhan unit pengajaran. (b) Biarkan siswa menemukan gagasan mereka dulu. (c) Kembangkan kepemimpinan, kerjasama, pencarian informasi, dan aktivitas siswa sebagai hasil dari proses belajar. (d) Gunakan pemikiran, pengalaman, dan minat siswa untuk mengarahkan proses pembelajaran. (e) Kembangkan penggunaan alternative sumber informasi baik dalam bentuk bahan tertulis maupun bahan-bahan para pakar. (f) Usahakan agar siswa mengemukakan sebab-sebab terjadinya suatu peristiwa dan situasi serta doronglah siswa agar mereka memprediksi akibat-akibatnya. (g) Carilah gagasan siswa sebelum guru menyajikan pendapatnya. (h) Buat agar siswa tertantang dengan konsepsi dan gagasan mereka sendiri. (i) Sediakan waktu cukup untuk berefleksi dan menganalisis, menghormati dan menggunakan semua gagasan yang diketengahkan seluruh siswa. (j) Doronglah siswa untuk melakukan analisis sendiri. (k) Gunakan masalah yang diidentifikasi oleh siswa sesuai minat dan dampak yang ditimbulkannya. (1) Gunakan sumber-sumber lokal. (m) Libatkan siswa dalam mencari informasi. (n) Perluas belajar seputar jam pelajaran, ruang kelas, dan lingkungan sekolah. (o) Pusatkan perhatian pada dampak sains pada setiap individu. (p) Pandanglah konten sains itu sebagai suatu yang semata-mata ada untuk dikuasai siswa melalui testing. (q) Tentukan kesadaran karier terutama yang berhubungan dengan sains dan teknologi.

Untuk mengetahui konstruktivisme dalam pengajaran maka terdapat beberapa hal yang menjadi pengamatan, diantaranya:

a. Siswa bekerja sendiri-sendiri dan punya inisiatif individu

Berdasarkan hasil pengamatan di lapangan diketahui bahwa sebagian besar siswa sudah mampu bekerja mandiri. Ini disebabkan karena setiap siswa selama pembelajaran berlang- sung diberikan LKS yang dapat memandu mereka bekerja serta penerapan komponen pembelajaran kontekstual ini dibarengi dengan pembelajaran kooperatif tipe TPS-berempat. Dalam pelaksanaanya pada pertemuan pertama, siswa belum terbiasa dengan metode pembelajaran kooperatif TPS-Berempat mereka lebih terbiasa dengan pembelajaran konvensional. Melalui tahapan kerja pertama pembelajaran kooperatif tipe TPSberempat setiap siswa mengerjakan LKS secara mandiri, kondisi ini sesuai dengan salah satu komponen konstruktivisme. Berdasarkan hasil pengamatan di lapangan ditemukan beberapa orang siswa belum mampu bekerja secara mandiri dan berinisiatif sendiri.

Tindakan guru dalam mengatasi permasalahan yang muncul adalah memberikan sosialisasi dan motivasi kepada siswa tersebut untuk mampu mengerjakannya secara mandiri. Kemudian pada tahapan berikut dari pembelajaran kooperatif tipe TPSberempat yaitu siswa mendiskusikan hasil temuannya dengan teman kelompok berdua dan dilanjutkan dengan kelompok berempat.

b. Guru membiarkan siswa berfikir setelah mereka disuguhi beragam pertanyaan-pertanyaan guru

Pada tahap pertama dari model pembelajaran kooperatif tipe TPS-berempat, siswa diminta memikirkan secara pribadi setiap permasalahan yang muncul dan ditanyakan dalam LKS sebelum nantinya dilanjutkan dengan diskusi kelompok. Berdasarkan pengamatan di lapangan untuk pertemuan awal, guru memandu siswa untuk menjawab pertanyaan yang ada dalam LKS. Kondisi ini disebabkan karena pada pembelajaran terdahulu siswa belum terbiasa belajar dengan LKS, sedangkan pada per- 
temuan berikutnya siswa tidak dipandu lagi.

c. Siswa mengkomunikasikan pemahamanya.

Berdasarkan pengamatan dilapangan, setelah siswa memikirkan jawaban secara individu kemudian dilanjutkan dengan diskusi kelompok berdua dan berempat, mereka cukup tertantang untuk mengkomunikasikan jawaban yang sudah mereka miliki dengan teman satu kelompok, hal ini disebabkan setiap kelompok terdiri dari gabungan siswa yang berkemampuan tinggi, sedang dan rendah. Setelah LKS selesai didiskusikan secara berkelompok (kelompok berdua dan kelompok berempat) maka beberapa orang siswa diminta mempresentasikan hasil temuan kelompoknya di depan kelas.

d. Guru membiarkan siswa bekerja secara otonom dan berinisiatif sendiri,

Berdasarkan pengamatan dilapangan pada pertemuan kedua dan berikutnya siswa sudah mampu bekerja secara otonom dan berinisiatif sendiri untuk menjawab dan mencari penyelesaian soal-soal yang ada pada LKS.

Dapat disimpulkan bahwa munculnya komponen Kontekstual bentuk konstruktivisme dinilai sudah baik. Artinya setiap siswa sudah mulai mengkonstruksi pengetahuannya dan memanfaatkan pengetahuan-pengetahuan yang sudah mereka miliki sebelumnya dari kehidupan sehari-harinya maupun dari buku pelajaran.

\section{Menemukan}

Kegiatan inkuiri sebenarnya adalah sebuah siklus. Ada beberapa langkah dalam kegiatan menemukan (inquiry) seperti yang dikemukakan Nurhadi (2004: 43) berikut ini:

a. Merumuskan masalah

b. Mengamati dan melakukan observasi:
1) Membaca buku atau sumber lain untuk mendapat informasi pendukung.

2) Mengamati dan mengumpulkan data sebanyak-banyaknya dari sumber atau objek yang diamati.

c. Menganalisis dan meyajikan hasil tulisan, gambar, laporan bagan, tabel, dan karya lainnya.

d. Mengkomunikasikannya atau menyajikan hasil karya pada pembaca, teman sekelas, guru, atau audiens yang lain:

1) Karya siswa disampaikan keteman sekelas atau kepada orang banyak untuk mendapatkan masukan.

2) Bertanya jawab dengan teman.

3) Memunculkan ide-ide baru.

4) Melakukan refleksi.

e. Penyimpulan (conclusion).

Dari hasil pengamatan di lapangan untuk LKS II dan III, siswa diminta untuk menyelesaikan LKS berupa soal cerita yang sederhana. Hampir sebagian besar siswa mampu untuk menyelesaikan ini. Sedangkan pada LKS IV dan V soal cerita yang diberikan cukup kompleks karena mencakup gabungan beberapa materi terdahulu. Pada bagian ini siswa agak sedikit kesulitan dalam bekerja secara individu untuk menggabungkan materi yang telah dipelajari terdahulu. Setelah tahap TPS-berempat dilanjutkan ke diskusi kelompok, siswa mulai leluasa untuk bertanya dan mengkomunikasikan ide sehingga mereka menemukan cara penyelesaian dari soalsoal yang diberikan.

Dengan demikian munculnya aspek menemukan pada siswa dalam pembelajaran terkategori baik. Beberapa siswa mampu menemukan konsep sendiri sedangkan beberapa siswa lainnya hanya mampu menemukan konsep setelah tahap kedua dari pembelajaran kooperatif tipe TPS-berempat terlaksana. Ini dimungkinkan karena ada siswa yang baru bisa menemukan konsep setelah 
mereka berdiskusi dengan teman lainnya dalam satu kelompok.

\section{Bertanya}

Selama pembelajaran berlangsung, dapat diamati bahwa sebagian besar siswa melakukan aktivitas bertanya. Bertanya yang dilakukan siswa tidak hanya terjadi antara guru dan siswa, tetapi lebih banyak terjadi antara siswa dan siswa dalam kelompok berdua dan juga antara siswa dan siswa dalam kelompok berempat. Kondisi ini terjadi karena siswa selama pembelajaran berlangsung berusaha untuk menyelesaikan setiap permasalahan yang mereka temukan dalam LKS. Mereka terfasilitasi untuk banyak bertanya dan saling bertukar informasi dalam pembelajaran kooperatif tipe TPSberempat. Setiap siswa berani menanyakan hal yang tidak dimengerti baik kepada teman sekelompok maupun pada guru. Dengan pembelajaran kooperatif tipe TPS-berempat ini siswa tertantang dan terfasilitasi untuk menunjukkan partisipasi mereka serta melakukan komunikasi.

\section{Masyarakat Belajar}

Masyarakat belajar yang dimunculkan dalam penelitian ini dan ditemukan di lapangan yaitu siswa bekerja berpasangan (kelompok berdua) dan berkelompok (kelompok berempat). Selama pembelajaran berlangsung selain belajar secara individu dalam kelompok, siswa juga melakukan diskusi dengan anggota kelompoknya. Dalam satu kelompok terdiri atas siswa berkemampuan rendah, sedang dan tinggi. Kondisi ini memungkinkan terjadi komunikasi dan diskusi yang baik antara siswa dalam satu kelompok. Pada bagian akhir pembelajaran kooperatif tipe TPS-berempat siswa melakukan sharing dengan teman selokal. Pada tahap ini beberapa siswa yang ditunjuk, mempresentasikan temuan kelompoknya di depan kelas dan siswa dari kelompok lain menanggapi hasil kerja temannya tersebut. Dalam kondisinya dilapangan selama pembelajaran berlangsung siswa saling bertukar informasi dan tidak malu untuk bertanya satu sama lainnya.

\section{Pemodelan}

Dari hasil pengamatan di lapangan terlihat bahwa pemodelan yang terjadi yaitu berupa hasil kerja siswa yang terlihat dalam presentasi kelompok yang dilakukannya di depan kelas. Pemodelan juga dapat dilakukan oleh guru ketika membimbing siswa dalam mengerjakan LKS. Selama pembelajaran terlihat bahwa guru bukanlah satu-satunya model tetapi siswa juga bisa dijadikan model dalam pembelajaran.

\section{Refleksi}

Dari hasil pengamatan terlihat bahwa siswa sedikit sekali mencatat apa yang telah dipelajari. Siswa hanya terfokus mengerjakan LKS. Refleksi lebih sering dilakukan dengan panduan guru yaitu pada saat akhir pembelajaran. Selama pembelajaran terlihat bahwa siswa sudah merasa cukup puas dengan mengerjakan LKS.

\section{Penilaian yang Sebenarnya}

Penilaian yang sebenarnya dilakukan dengan tujuan untuk melihat gambaran perkembangan belajar siswa. Penilaian dilakukan selama proses pembelajaran berlangsung dan juga pada akhir pokok bahasan. Artinya guru sudah melaksanakan penilaian yang sebenarnya dengan berbagai macam cara untuk melihat kemajuan belajar siswa selama proses pembelajaran.

\section{Kemampuan Pemahaman Konsep Matematika}

Kemampuan pemahaman konsep adalah kemampuan siswa dalam merumuskan prinsip-prinsip matematika. Kemampuan pemahaman konsep siswa yang didasarkan pada hasil postes untuk kedua kelas penelitian. Perangkat pene- 
litian yang digunakan untuk memperoleh nilai postes terlebih dahulu telah dikembangkan dengan mengikuti langkahlangkah dalam pengembangan instrument. Instrumen ini dikembangkan melalui beberapa tahap, yaitu: tahap pembuatan instrumen, tahap penyaringan instrumen, dan tahap uji coba instrumen untuk tes kemampuan pemahaman konsep matematika.

Penelitian ini menggunakan instrumen untuk mengumpulkan data yaitu lembar observasi tes hasil belajar yang diberikan diakhir pokok bahasan. Lembaran Kegiatan Siswa (LKS) digunakan untuk penilaian kinerja kelompok selama pembelajaran dengan pendekatan kontekstual melalui pembelajaran kooperatif tipe TPS-berempat.

Sebelum instrumen digunakan, terlebih dahulu divalidasi. Proses validasi dilakukan oleh tiga orang ahli/pakar yang merupakan dosen jurusan Matematika UNP dengan menggunakan lembar validasi. Rancangan instrumen pembelajaran direvisi menurut komentar dan saran dari validator dan pembimbing. Setelah perbaikan selesai dilakukan dan dinyatakan layak, maka instrumen digunakan di lapangan.

\section{Tes Hasil Belajar Pemahaman Konsep}

Penguasaan konsep dalam matematika ada beberapa tingkat, yaitu: mengucapkan konsep dengan tepat dan benar; menjelaskan konsep dengan kalimat dan kata-kata biasa; mengidentifikasi keberlakuan dan ketidak berlakuan konsep; menginterpretasikan suatu konsep; menerapkan konsep dengan benar. Hasil postes pemahaman konsep siswa di kelas eksperimen dan kelas kontrol dapat dilihat pada tabel berikut.

Tabel Hasil Postes Pemahaman Konsep

\begin{tabular}{lllll}
\hline Keterangan & $\mathrm{X}_{\max }$ & $\mathrm{X}_{\min }$ & $\begin{array}{l}\text { Rata- } \\
\text { rata }\end{array}$ & $\begin{array}{l}\text { Simp. } \\
\text { Baku }\end{array}$ \\
\hline Eksperimen & 32 & 12 & 22,68 & 6,88 \\
\hline Kontrol & 28 & 3 & 12,44 & 7,15
\end{tabular}

Pada tabel di atas terlihat bahwa rata-rata pemahaman konsep siswa yang diajar dengan pembelajaran kontekstual melalui model pembelajaran kooperatif TPS-berempat lebih tinggi dari pada pembelajaran konvensional. Berdasarkan data simpangan baku maka skor pemahaman konsep siswa yang diajar dengan pembelajaran konvensional menyebar dibandingkan yang diajar dengan pembelajaran kontekstual melalui model pembelajaran kooperatif TPS-berempat. Skor maksimum dan skor minimum pemahaman konsep untuk kelas eksperimen lebih tinggi dibandingkan dengan kelas kontrol, sehingga dapat disimpulkan bahwa kemampuan pemahaman konsep matematika siswa yang belajar dengan menggunakan pendekatan pembelajaran kontekstual melalui pembelajaran kooperatif TPS-berempat lebih baik dibandingkan dengan siswa yang belajar dengan pendekatan konvensional. Hal ini disebabkan karena kemampuan siswa dalam berfikir, mengkonstruksi ide dan mengembangkan pemahman lebih terfasilitasi bila menggunakan pendekatan pembelajaran kontekstual melalui model pembelajaran kooperatif TPSberempat.

Selama proses pembelajaran berlangsung siswa mampu mengkonstruksi sendiri ataupun bersama kelompok belajarnya tentang pengertian dari beberapa istilah yang ada dalam materi pembelajaran, misalnya: siswa dapat memberikan beberapa pengertian tentang apa yang disebut sebagai harga jual, harga beli, untung, dan rugi serta kapan kondisi ini terjadi. Siswa juga dapat menentukan harga keseluruhan dan harga per-unit. Kondisi ini berdampak baik bagi kemampuan siswa dalam menyelesaikan soal-soal tes yang terkait dengan pemahaman konsep yang salah satunya seperti pada soal "Harga beli lima ekor ayam $\mathrm{Rp} 62.500,00$. Jika dua ekor ayam dijual dengan harga $\mathrm{Rp}$ 13.500,00 dan sisanya dijual dengan 
harga Rp 11.000,00, maka berapakah total penjualan ayam tersebut dan besarnya untung atau rugi dari penjualan ayam tersebut?". Siswa mampu mengkonstruksi berapa harga keseluruhan dari penjualan ayam tersebut dan membandingkan dengan harga pembeliannya. Selanjutnya mereka juga dapat menentukan apakah seorang pedagang tadi mengalami untung atau rugi dari penjualan yang dilakukannya.

Hal ini sesuai dengan kajian teori (Nurhadi, 2004: 9) menyatakan bahwa "pembelajaran kontekstual adalah kaidah pembelajaran yang menggabungkan isi kandungan dengan pengalaman harian individu, masyarakat dan alam pekerjaan". Pembelajaran kontekstual juga memungkinkan para siswa untuk memperkuat, mengembangkan dan menerapkan pengetahuan akademik serta keterampilan mereka pada berbagai lingkungan sekolah maupun luar sekolah, dalam rangka memecahkan permasalahan riil. Pembelajaran kooperatif TPS-Berempat menurut Nurhadi (2004: 66) adalah struktur yang dapat digunakan untuk meningkatkan penguasaan akademik.

\section{Hasil Belajar pada Aspek Pemahaman Konsep}

Hasil temuan di lapangan menunjukkan pemahaman konsep siswa yang diajar dengan pembelajaran kontekstual melalui model pembelajaran kooperatif tipe TPS-berempat lebih baik dari pemahaman konsep siswa dengan pembelajaran konvensional. Berdasarkan hasil tes dan pengamatan di lapangan ditemukan bahwa dalam pembelajaran dengan pendekatan kontekstual yang sudah dilakukan, siswa mampu mengkonstruksi sendiri pengetahuan-pengetahuan yang ada karena bersumber dari lingkungan mereka sendiri sehingga mereka benarbenar menemukan seperangkat fakta. Lembar Kerja Siswa yang dikerjakan setiap pertemuan dapat memandu dan memancing ingatan siswa terhadap apa yang telah diketahuinya kemudian memadukan dengan materi pembelajaran yang sedang dipelajari. Permasalahan yang dibahas juga merupakan permasalahan matematika yang bersifat terbuka dan sangat dekat dengan kehidupan mereka sehari-hari. Berdasarkan teori, menurut Wina (2006: 73) "pendekatan kontekstual merupakan suatu strategi pembelajaran yang menekankan pada proses keterlibatan siswa secara penuh untuk dapat menemukan materi yang dipelajari dan menghubungkan dengan situasi kehidupan nyata sehingga mendorong siswa untuk dapat menerapkannya dalam kehidupan nyata".

Dalam pembelajaran dengan penerapan pendekatan kontekstual, siswa melakukan kegiatan penemuan dengan teman sekelompoknya baik kelompok berdua maupun kelompok berempat. Melalui pembelajaran kooperatif TPSberempat setiap siswa dapat lebih leluasa berdiskusi dengan teman sekelompoknya. Dengan demikian mereka dapat lebih memahami konsep yang ada dengan sebaik-baiknya. Hal ini senada dengan pendapat Anita Lie (2002: 56) yang menyatakan bahwa teknik TPS-berempat ini memberi kesempatan kepada siswa untuk bekerja sendiri dan bekerja dengan orang lain serta optimalisasi pertisipasi siswa. Akibatnya pemahaman konsep akan lebih bermakna bagi siswa karena mengerti arti belajar, apa manfaat yang dipelajari dan bagaimana mencapainya.

Pada pembelajaran secara konvensional konsep-konsep diperkenalkan dalam bentuk ceramah. Siswa lebih banyak duduk terdiam mendengarkan informasiinformasi yang disampaikan oleh guru dan kurang mencari informasi dari sumber lain. Dalam pembelajaran secara konvensional ini hanya beberapa orang saja yang mau bertanya dan memberi tanggapan tentang materi pelajaran yang sedang diajarkan guru. Apabila ditanya atau diminta menjelaskan konsep siswa tidak mampu menjelaskan konsep ter- 
sebut dengan bahasa mereka sendiri. Tidak jarang mereka membuka kembali catatan atau buku dan membacakannya.

Berdasarkam pengamatan penulis selama proses pembelajaran dengan pendekatan pembelajaran kontekstual melalui model pembelajaran kooperatif TPS-berempat terlihat bahwa siswa mampu menuliskan konsep dengan tepat dan benar serta mampu menjelaskan konsep dengan bahasa mereka sendiri. Pembelajaran ini memberikan kesempatan yang lebih banyak kepada siswa untuk bisa menemukan sendiri ataupun berkelompok setiap permasalahan dan konsep. Keunggulan pendekatan kontekstual melalui pembelajaran kooperatif tipe TPS-berempat adalah pengetahuan dikonstruksi sendiri oleh siswa dari masalah-masalah yang diberikan guru yang ada dalam kehidupan sehari-hari maupun dari LKS yang tersedia, siswa mampu membuat asumsi sehingga akhirnya siswa menemukan sendiri konsep pembelajaran yang dibutuhkan. Konsep yang didapat dari menemukan sendiri akan lebih lama bertahan dalam ingatan siswa sehingga pembelajaran yang didapat lebih bermakna. Dari penjelasan di atas dapat dikatakan bahwa hal-hal tersebutlah yang merupakan penyebab terjadinya hasil belajar untuk pemahaman konsep siswa yang diajar dengan pendekatan pembelajaran kontekstual melalui model pembelajaran kooperatif TPS-berempat lebih baik dari pada dengan pembelajaran konvensional.

\section{PENUTUP}

Penelitian ini merupakan penelitian yang membandingkan penggunaan dua pendekatan pembelajaran, yaitu pendekatan pembelajaran kontekstual melalui model pembelajaran kooperatif TPS-Berempat dan pendekatan konvensional. Berdasarkan analisa data yang telah dikemukakan, maka dapat ditarik beberapa kesimpulan dari penelitian ini, diantaranya yaitu: Pemahaman konsep siswa yang diajar dengan pendekatan kontekstual melalui model pembelajaran kooperatif TPS-Berempat dalam pembelajaran matematika lebih baik dari pemahaman konsep siswa yang diajar secara konvensional dan kemunculan aspek-aspek pendekatan pembelajaran kontekstual dapat meningkatkan hasil belajar pemahaman konsep matematika siswa.

Berdasarkan hasil penelitian yang dikemukakan di atas dapat diketahui bahwa penggunaan pendekatan kontekstual melalui model pembelajaran kooperataif TPS-Berempat pada mata pelajaran matematika pokok bahasan aritmatika sosial di SMP N 20 Padang ternyata cukup efektif untuk meningkatkan hasil belajar matematika siswa pada pemahaman konsep matematika. Keuntungan pendekatan kontekstual melalui model pembelajaran koopertaif TPS-Berempat adalah materi pembelajaran dikaitkan dengan pengalaman sehari-hari dan dalam pembelajaran kooperatif adanya saling ketergantungan positif, saling membantu, saling memberikan motivasi sehingga ada interaksi positif, sedangkan peran guru terus melakukan pemantauan melalui observasi dan memberi arahan pada siswa.

Berdasarkan kesimpulan yang telah dikemukakan di atas, maka pendekatan kontekstual melalui model pembelajaran koopertaif TPS-Berempat dapat dijadikan salah satu alternative untuk memperbaiki dan meningkatkan hasil belajar matematika siswa khususnya untuk aspek pemahaman konsep matematika. 


\section{DAFTAR RUJUKAN}

Arikunto, S, 2007. Dasar-Dasar Evaluasi Pendidikan. (Edisi Revisi). Jakarta: Bumi Aksara.

-------, 1996. Prosedur Penelitian Suatu Pendekatan Praktek. Jakarta: Bumi Aksara.

Anita, Lie, 2001. Cooperative.

Dahar W R, 1989. Teori-teori Belajar. Erlangga: Jakarta.

Depdikbud. 1994. Garis-Garis Besar Program Pengajaran Mata Pelajaran Matematika SMP. Jakarta: Depdikbud.

Hamzah B. uno. 2008. Model Pembelajaran. Jakarta: Erlangga.

Mulyono, Abdurrahman, 1998. Pendidikan Bagi Anak Berkesulitan Belajar. Jakarta: Rineka Cipta

Nurhadi dan Agus Gerrad dkk, 2004. Pendekatan Kontekstual (Contekstual Teaching and Learning/CTL) dan Penerapannya dalam KBK. Malang: Universitas Negeri Malang.

NCTM. 1989. Curriculum and Evaluation Standards for School Mathematics. Reston, VA: NCTM
Oemar Hamalik, 2008. Kurikulum dan Pembelajaran. Jakarta: Bumi Aksara.

Peraturan Pemerintah Republik Indoneia Nomor 19 tahun 2005 tentang Standar Nasional Pendidikan, 2005. Jakarta: Diperbanyak oleh Penerbit Sinar Grafika.

Permendiknas 2006 Tentang SI dan SKL. 2006. Jakarta: diperbanyak oleh Sinar Grafika Offset

Slavin, RE. 1994. Educational Psicology Theory: Theory \& Practice (Fourth Edition). Massachusetts: Allyn and Bacon Publishers.

Suharsimi, Arikunto, 1997. Dasar-dasar Evaluasi Pendidikan. Jakarta: Bumi Aksara.

Suherman, E dkk. 2001. Strategi Pembelajaran Matematika Kontemporer. JICA. UPI Bandung.

Undang-undang Republik Indonesia No. 20 Tahun 2003 tentang Sistem Pendidikan Nasional. 2003. Jakarta: Diperbanyak oleh Sinar Grafika Offset.

Wina, Sanjaya, 2006. Strategi Pembelajaran Berorientasi Standar Proses Pendidikan, Jakarta: Kencana Prenada Media. 